\title{
DIGITAL DEVELOPMENT AND ECONOMIC GROWTH IN SELECTED ASEAN COUNTRIES: APPLYING RESPONSE SURFACES FOR CRITICAL BOUNDS OF COINTEGRATION TEST
}

\author{
Jarita Duasa* \& Aisha Elalim Ramadan \\ ${ }^{*}$ First author \\ Department of Economics \\ Kulliyyah of Economics and Management Sciences \\ International Islamic University Malaysia \\ Kuala Lumpur, Malaysia. \\ (jarita@iium.edu.my; aramadan67@gmail.com) \\ DOI: https://doi.org/10.22452/jati.vol24no2.1
}

\begin{abstract}
The study attempts to analyse the relationship between digital development and economic growth in selected ASEAN economies using small sample data. Using bound testing technique of cointegration, the new critical values of the test are recalculated to fit for small sample data of each country based on response surface in order to obtain rigorous results without ignoring the individual country analysis. The results show that long-run positive impact of digital transformation on economic growth is profound in Malaysia and the Philippines. However, in short-run, most countries in the region, regardless of income level or economic development, encountered negative implication of digital transformation on growth due to digital divide caused by the diversity of the member countries of ASEAN that might affect the accessibility and connectivity of network in the process of transformation.
\end{abstract}

Keywords: economic growth, digital revolution, cointegration, response surface

\section{Introduction}

The Association of Southeast Asian Nations (ASEAN) countries are among the countries in the world that strive hard to keep up with other developed countries 
in the fast-moving global digital economy. Having good fundamentals, such as, economic growth at $6 \%$ per year, the rapid growth of smartphone penetration of around 35\% with well-developed information and communication technology (ICT), ASEAN countries have good potential to be at the higher ranking of the countries who have the fast-growing digital economy in the world by 2025. It is expected that by 2025, a digital revolution will transform these countries' economic activities into more efficient and productive through the development of digital services especially in the sectors of e-commerce and advance mobile financial services.

The expansion of the digital economy recently in these ASEAN economies has provided an important source of the countries' economic growth. The major players identified in this digital development include Facebooks, Microsoft, Apple, Google and Amazon. Even firms in ASEAN countries are quickly adopting ICT, and they have done it at a fast pace than the global average. Moreover, the ICT sector is growing very fast in the countries, and it is estimated that ICT sector accounts for about $3 \%$ of total value added in the region currently (Macroeconomic Review, April 2018). However, there is considerable variation between countries with ICT value-added shares ranging from $0.7 \%$ to $5.4 \%$. The countries which contribute more to this portion are Indonesia, Malaysia and Singapore. In the term of investment, the ICT investment in ASEAN amounted to more than US\$100 billion in 2014 and now growing by more than 15\% annually (AT Kearney and Axiata, 2015). It is expected that the digital economy could also enhance ASEAN economic integration and promoting financial inclusion in the region. This is obviously an important agenda of the ASEAN Economic Community (AEC) formation, particularly under the AEC Blueprint 2025 (ASEAN, 2015).

Past literature on studies of digital revolution in developing countries includes a substantial amount of empirical evidence that reveals the situations where information systems projects take shape within communities striving to improve their life conditions (Odedra-Straub 1996, Avgerou and Walsham 2000, Sahay 2000, Krishna and Madon 2002, Bhatnagar and Bjorn-Andersen 1990, Bhatnagar and Odedra 1992). In many macroeconomics studies, from the supplyside, ICT or digital development is expected to raise GDP growth, productivity and real wages through several channels: (i) the ICT-producing sector itself is a source of growth; (ii) ICT investments add to the capital stock that is available to workers and thus raise labour productivity; and (iii) ICT enables firms to combine labour and capital inputs more efficiently, enhancing total factor productivity (TFP). 
A World Bank study by Preker, Bos, Wang, Peabody, and Jamison (1999) had found that through the cross-country studies, technological change accounts for a large portion of differences in growth rates. More importantly, the study emphasised that technological innovation enhances human capabilities - such as a healthy life, knowledge, creativity, and participation in the social, economic, and political life of a community - and impacts on economic growth through productivity gains. At the same time, human capabilities are an important means for achieving technological innovation. Therefore, technology innovation and development are 'mutually reinforcing, creating a virtuous circle'. This conclusion reflects a dynamic relationship between technology innovation and development, which goes beyond the static association of ICT diffusion and growth rates.

The report on the 'networked world' begins with the statement that 'the Internet and other ICTs have fundamentally changed the way the world works' (Kirkman, Cornelius, Sachs, \& Schwab, 2002). It then sets out to analyse, understand, and measure the link between digital development and economic growth, with a particular focus on the issues of developing countries. The economic reasoning of its premise on the role of ICT in the development process is that the technology enhances the functioning of the markets because it provides information to producers and consumers in order to help them make efficient choices (Eggleston, Jensen, \& Zeckhauser, 2002). They also presented findings on the correlation of telephone diffusion and improved economic indicators in Chinese villages-though the authors are aware that such a correlation may suggest a reverse causality, that is, the diffusion of telephones following economic growth that resulted from other factors. However, other economic and non-economic mechanisms may negate the creation of the predicted benefits. The relationship between ICT and economic growth implicates processes of change of social and individual behaviour that are poorly understood.

The rationale for the role of ICT in economic growth has also been advanced by Ngwenyama, Andoh-Baidoo, Bollou, and Morawczynski (2006) and Mbarika, Payton, Kvasny, and Amadi (2007). They attempted to address the concerns of the opponents. The opponents question the developmental effectiveness of national and international policy initiatives that direct resources to bridging the digital divide and they argue that these are unlikely to achieve economic growth effects because there are no human capabilities, or economic conditions for their use (Warschauer, 2003; Wade, 2004). For example, research that examined the sustainability failure of telecentres that were intended to provide market information sources to rural villages showed the concerns that 
drive people's participation or distance from such innovation, despite its developmental promise (Harris, Kumar, \& Balaji, 2003; Bailur, 2007). Similarly, socially embedded analyses of business information system innovation cases show some of the reasons why the 'productivity paradox' of continuing ICT diffusion without the expected productivity increases continue in developing countries (Mann 2004). Nevertheless, as a whole, most research tends to accept the assumption that digital revolution potentially contributes to economic growth. All these arguments indicate a need to take a closer look at the reasoning that sustains the tool-and-effect association of digital revolution and economic development, particularly in developing countries.

Since digital development is a very recent development in most ASEAN countries, data that would able to be collected are very small in size, particularly for time series data. Using small data in modelling the relationship between variables might end up with spurious or insignificant results. Because of this factor, most previous studies are using panel data in their analyses which fail to analyse the impact of digital transformation on growth in each individual member country. Thus, the current study attempts to model the relationship between digital and economic growth variables using these small sample timeseries data. This objective is expected to be achieved by adopting new method of generating critical values of the cointegration test with small sample data to obtain rigorous results without ignoring the individual country analysis.

\section{Data and Methodology}

The study adopts the cointegration technique to analyse the relationship between digital development and economic growth for selected ASEAN member countries. The cointegration technique of analysing the relationship between variables is widely used in macroeconomics. Many studies used a test of cointegration based on an F-test for the joint significance of the terms of the level in an error correction model. Some studies tested the cointegration among variables using a t-test of a single error correction term.

A study by Pesaran, M., Shin, Y. and Smith, R. (2001) came out with another cointegration test without preconditions on the order of integration of the variables entering the relationship but required big sample size data. Narayan (2004) adopted a similar test and developed new critical values for the test based on small sample size data ranging from 30 to 80. Later, Turner (2006) extended further the effort to improve the cointegration test by presenting response surfaces for the F-test of cointegration model with the advantage of enabling the user to generate critical values of the test for different sample size, which means it can be applied to a very small sample size data. 
Thus, this study will adopt the F-test of cointegrating technique following Pesaran, Shin, and Smith (2001) but the critical values of the test will be self-calculated using the response surface technique suggested by Turner (2006). Testing for the cointegration can be done by testing the joint significance of the level terms in an error-correction equation linking two/more variables of interest, as shown below:

$$
\Delta y_{t}=\alpha_{0}+\alpha_{1} \Delta x_{t}+\alpha_{2} y_{t-1}+\sum_{j=1}^{k-1} \alpha_{2+1} x_{j t-1}+\alpha_{2+k} t+u_{t}
$$

where $\mathrm{k}-1$ is the number of variables in the regression and $\mathrm{t}$ is the trend. The null hypothesis in this case is Ho: $\alpha_{2}=\alpha_{3} \ldots \ldots \ldots \ldots=\alpha_{2+\mathrm{k}-1}=0$. The critical values for the cointegration test suggested by Pesaran et al. (2001) show that it is possible to set the bounds for them. The upper bound is determined by the case in which $x$ variables are all integrated of order one and there is no cointegration relationship between them. The lower bound is determined by the case in which $x$ variables are stationary or $\mathrm{I}(0)$. It is possible to reject the null hypothesis of no cointegration if the test statistics is above the upper bound, and it is not possible to reject it if the statistic is below the lower bound. If it lies between the upper and lower bounds, it requires more information before one can either accept or reject the null. Pesaran et al. (2001) provide a range of asymptotic critical values based on Monte Carlo analysis which correspond to different assumptions concerning the underlying data generation process (inclusion or exclusion of the constant and time trend in the model).

As for this present study, the test statistics are compared against the critical values which are self-calculated based on response surface suggested by Turner (2006) of the form:

$$
C_{i}(p)=\beta_{0}+\frac{\beta_{1}}{T}+\frac{\beta_{2}}{T^{2}}+\varepsilon_{i}
$$

where $C_{i}(p)$ denotes the $p \%$ quantile estimate for the $i$ th experiment, $\beta$ 's values are based on response surface estimates produced by Turner (2006), $\mathrm{T}$ is a sample size and $\varepsilon_{t}$ is a random walk.

As of data, the current study is using data sourced from the World Bank website. We use two indicators for the digital development variable as an independent variable in the growth model. Those are 'mobile cellular subscriptions' and 'fixed broadband subscriptions'. The study uses yearly data and two models developed using each indicator of the digital variable, namely 
Model 1 and Model 2, respectively. Other independent variables which also included in the model are 'gross fixed capital formation' and 'labour force participation rate' while the dependent variable is 'real GDP per capita'. Table 1 displays the details of data sources. Data are collected on selected ASEAN countries, namely, Malaysia, Indonesia, Thailand, Vietnam, Singapore, Brunei, the Philippines and Cambodia, based on data availability. The sample size data for each country using two indicators of digital development are shown in Table 2.

Table 1: Data and Variables

\begin{tabular}{|l|l|l|}
\hline Data/Variable & Measurement & $\begin{array}{l}\text { Sources of } \\
\text { data }\end{array}$ \\
\hline Real Gross Domestic Product Per capita (Y) & US\$ & World Bank \\
\hline Real Gross Fixed Capital Formation (K) & US\$ & World Bank \\
\hline Labour Force Participation Rate (L) & $\begin{array}{l}\%+ \\
15+\end{array}$ & World Bank \\
\hline Mobile Cellular Subscription(MOB) & Unit & World Bank \\
\hline Fixed Broadband Subscription (BB) & Unit & World Bank \\
\hline
\end{tabular}

(Source: Authors' computation.)

Table 2: Sample Size Data for Each Selected Country in Study

\begin{tabular}{|l|c|c|c|c|}
\hline Country & $\begin{array}{c}\text { Sample size } \\
\text { (using 'mobile } \\
\text { cellular } \\
\text { subscriptions' as } \\
\text { an indicator of } \\
\text { digital } \\
\text { development) }\end{array}$ & Years & $\begin{array}{c}\text { Sample size } \\
\text { (using 'fixed } \\
\text { broadband } \\
\text { subscriptions' as an } \\
\text { indicator of digital } \\
\text { development) }\end{array}$ & Years \\
\hline Malaysia & 30 & $1986-2015$ & 15 & $2001-2015$ \\
\hline Indonesia & 26 & $1990-2015$ & 16 & $2000-2015$ \\
\hline Thailand & 26 & $1990-2015$ & 13 & $2003-2015$ \\
\hline Vietnam & 22 & $1994-2015$ & 14 & $2012-2015$ \\
\hline Singapore & 26 & $1990-2015$ & 18 & $1998-2015$ \\
\hline Brunei & 26 & $1990-2015$ & 15 & $2001-2015$ \\
\hline The Philippines & 23 & $1991-2015$ & 15 & $2001-2015$ \\
\hline Cambodia & $1993-2015$ & 14 & $2002-2015$ \\
\hline
\end{tabular}

(Source: Authors' computation.) 


\section{Empirical Findings}

The unit root tests results are displayed in Table 3 for each country in the study. In any case that shows there are mixed orders of integration among the variables, namely $\mathrm{I}(0)$ and $\mathrm{I}(1)$, it enables the study to adopt bound cointegration test developed by Pesaran et al. (2001). From the results of unit roots tests displayed, all countries, except Thailand, Vietnam and Cambodia, are having main variables stationary at $\mathrm{I}(0)$ and $\mathrm{I}(1)$. In these 3 countries, the main variables such as $\mathrm{Y}, \mathrm{K}$ or/and $\mathrm{L}$ are $\mathrm{I}(2)$ which not allow the bound test of cointegration to be conducted based on Pesaran et al. (2001). Thus, the three countries are dropped from the analysis. As for the Philippines, one indicator of digital variable, which is $\mathrm{BB}$, is $\mathrm{I}(2)$ which enable the cointegration test to be conducted using another indicator of digital variable, that is MOB. For Singapore, we only choose the model using MOB as most of the other main variables are $\mathrm{I}(0)$ or $\mathrm{I}(1)$ using the $\mathrm{ADF}$ unit root test.

Table 3: Unit Root Tests

\begin{tabular}{|c|c|c|c|c|}
\hline \multirow[t]{2}{*}{ Variable } & \multicolumn{2}{|c|}{$\begin{array}{l}\text { ADF test statistics } \\
\text { (with trend and intercept) }\end{array}$} & \multicolumn{2}{|c|}{$\begin{array}{c}\text { P-P test statistics } \\
\text { (with trend and intercept) }\end{array}$} \\
\hline & Level & First Difference & Level & First Difference \\
\hline \multicolumn{5}{|c|}{ Malaysia } \\
\hline $\ln Y$ & -1.999 & $-4.972^{* * *}$ & -1.999 & $-4.972^{* * *}$ \\
\hline $\ln K$ & -2.021 & $-4.280^{* * *}$ & -2.082 & $-4.280^{* * *}$ \\
\hline $\ln L$ & -2.569 & $-3.509^{*}$ & $-4.493^{* * *}$ & $-23.765^{* * *}$ \\
\hline $\operatorname{lnMOB}$ & -0.261 & $-4.981^{* * *}$ & 1.788 & $-9.352^{* * *}$ \\
\hline $\operatorname{lnBB}$ & $-6.355^{* * *}$ & -1.73 & $-11.496^{* * *}$ & -1.462 \\
\hline \multicolumn{5}{|c|}{ Indonesia } \\
\hline $\ln Y$ & -1.295 & $-3.569^{* *}$ & -1.531 & $-3.534^{* *}$ \\
\hline $\ln K$ & -2.352 & $-4.041^{* *}$ & -1.554 & -3.211 \\
\hline $\ln \mathrm{L}$ & $-3.497^{*}$ & $-4.135^{*}$ & -2.589 & $-10.627^{* * *}$ \\
\hline $\operatorname{lnMOB}$ & 3.681 & $-3.861^{* *}$ & 1.094 & $-3.898^{* *}$ \\
\hline $\operatorname{lnBB}$ & -0.949 & $-3.431^{*}$ & -1.021 & $-3.431^{*}$ \\
\hline \multicolumn{5}{|c|}{ Thailand } \\
\hline $\ln Y$ & -2.963 & $-3.313^{*}$ & -2.485 & $-3.318^{*}$ \\
\hline $\ln K^{a}$ & -2.463 & -2.971 & -1.822 & -2.970 \\
\hline $\ln \mathrm{L}$ & $-4.047^{* *}$ & $-3.699^{*}$ & $-4.907^{* * *}$ & -3.198 \\
\hline $\operatorname{lnMOB}$ & -1.678 & $-3.593^{*}$ & -1.344 & -2.899 \\
\hline $\operatorname{lnBB}{ }^{b}$ & -2.574 & -3.459 & $-17.866^{* * * *}$ & $-34.053^{* * *}$ \\
\hline \multicolumn{5}{|c|}{ Vietnam } \\
\hline $\ln Y$ & $-4.203^{* *}$ & -2.248 & -2.194 & -2.460 \\
\hline $\ln K$ & -1.205 & $-4.092^{* *}$ & -1.271 & $-4.092^{* *}$ \\
\hline $\operatorname{lnL^{a}}$ & -1.406 & -2.355 & 0.499 & -2.158 \\
\hline $\operatorname{lnMOB}$ & -1.169 & $-3.794^{* *}$ & -1.228 & $-3.795^{* *}$ \\
\hline
\end{tabular}




\begin{tabular}{|c|c|c|c|c|}
\hline $\ln B B$ & $-8.481^{* * *}$ & -0.825 & $-8.725^{* * *}$ & -0.602 \\
\hline \multicolumn{5}{|c|}{ Singapore } \\
\hline $\ln Y$ & -2.817 & $-4.724^{* * *}$ & -2.465 & $-6.367^{* * *}$ \\
\hline $\ln K$ & $-4.507^{* * *}$ & -2.992 & -2.103 & -2.956 \\
\hline $\ln L$ & -1.832 & $-4.774^{* * *}$ & -1.832 & $-4.774^{* * *}$ \\
\hline $\ln \mathrm{MOB}$ & -0.739 & $-4.261^{* * *}$ & -0.739 & $-4.264^{* * *}$ \\
\hline $\ln B B$ & -3.245 & -2.581 & $-14.259^{* * *}$ & -2.732 \\
\hline \multicolumn{5}{|c|}{ Brunei } \\
\hline $\ln Y$ & -0.7122 & $-5.080^{* * *}$ & -1.430 & $-3.634^{* *}$ \\
\hline $\ln K$ & -2.056 & $-4.928^{* * *}$ & -2.056 & $-5.005^{* * *}$ \\
\hline $\ln L$ & -1.132 & $-3.472^{*}$ & -0.254 & -2.626 \\
\hline $\ln \mathrm{MOB}$ & -2.279 & $-5.286^{* * *}$ & -1.655 & $-3.502^{*}$ \\
\hline $\ln B B$ & -1.671 & $-3.572^{*}$ & -2.312 & $-4.061^{* *}$ \\
\hline \multicolumn{5}{|c|}{ The Philippines } \\
\hline $\ln Y$ & -1.259 & $-4.881^{* * *}$ & -1.267 & $-5.086^{* * *}$ \\
\hline $\ln K$ & -1.108 & $-3.692^{* *}$ & -1.109 & $-5.000^{* * *}$ \\
\hline $\ln \mathrm{L}$ & -2.549 & $-5.873^{* * *}$ & -2.513 & $-5.863^{* * *}$ \\
\hline $\ln \mathrm{MOB}$ & -0.719 & $-4.993^{* * *}$ & 0.034 & $-6.754^{* * *}$ \\
\hline $\operatorname{lnBB} B^{a}$ & -0.331 & -2.344 & -0.277 & -2.128 \\
\hline \multicolumn{5}{|c|}{ Cambodia } \\
\hline $\ln Y^{a}$ & -2.913 & -2.565 & -1.970 & -2.565 \\
\hline $\ln K$ & -3.017 & $-4.030^{* *}$ & -2.959 & $-9.714^{* * *}$ \\
\hline $\ln L$ & $-4.890^{* * *}$ & -2.911 & -2.482 & -3.186 \\
\hline $\ln \mathrm{MOB}$ & 0.809 & $-4.493^{* * *}$ & 0.809 & $-4.523^{* * *}$ \\
\hline $\operatorname{lnBB}$ & -2.681 & $-3.709^{*}$ & -2.593 & $-3.709^{*}$ \\
\hline
\end{tabular}

Notes: $\quad * * *$ significant at $1 \%,{ }^{* *}$ significant at $5 \%,{ }^{*}$ significant at $10 \%$ athe variable is stationary at second difference or I(2) using both ADF and PP tests bthe variable is stationary at second difference or I(2) using ADF test

\section{(Source: Authors' computation.)}

The next step is to estimate equation (1) to analyse the long-run relationship among variables for Malaysia, Indonesia, Singapore, Brunei and the Philippines. Results of the $F$ - test for the cointegration are shown in Table 4 . The results show that using $\mathrm{MOB}$ as an indicator of digital variable, there are cointegration relationship between variables inserted in the model for Malaysia, Indonesia, Brunei, the Philippines and Singapore. Results displayed in Table 5, using $\mathrm{BB}$ as an indicator of the digital variable, show the cointegration relationship among variables in the model existed for Indonesia and Brunei but not for Malaysia. The $F$ - statistics in most cases are higher than the upper bound critical value at $10 \%, 5 \%$ and $1 \%$ significant level using unrestricted intercept and no trend. As mentioned earlier, the adjusted bound critical values are calculated based on the response surface developed by Turner (2006). 
Table 4: F-Statistics for Cointegration Relationship (Model 1- Using MOB)

\begin{tabular}{|c|c|c|c|c|c|}
\hline $\begin{array}{l}\text { F-test } \\
\text { statistics }\end{array}$ & Lag & $\begin{array}{l}\text { Sig. } \\
\text { level }\end{array}$ & $\begin{array}{l}\text { Adjusted Bc } \\
\text { Values* (un } \\
\text { intercept an }\end{array}$ & & Outcome \\
\hline \multicolumn{6}{|c|}{ Malaysia } \\
\hline \multirow[t]{4}{*}{6.977} & \multirow[t]{4}{*}{4} & \multirow{4}{*}{$\begin{array}{l}1 \% \\
5 \% \\
10 \% \\
\end{array}$} & $\mathrm{I}(0)$ & $\mathrm{I}(1)$ & \multirow{4}{*}{$\begin{array}{c}\text { There is cointegration } \\
\text { at } 5 \% \text { sig level (reject } \\
\left.\mathrm{H}_{0}\right)\end{array}$} \\
\hline & & & 6.328 & 7.993 & \\
\hline & & & 4.260 & 5.538 & \\
\hline & & & 3.416 & 4.532 & \\
\hline \multicolumn{6}{|c|}{ Indonesia } \\
\hline \multirow[t]{4}{*}{5.766} & \multirow[t]{4}{*}{4} & \multirow{4}{*}{$\begin{array}{l}1 \% \\
5 \% \\
10 \% \\
\end{array}$} & $\mathrm{I}(0)$ & $\mathrm{I}(1)$ & \multirow{4}{*}{$\begin{array}{c}\text { There is cointegration } \\
\text { at } 5 \% \text { sig level (reject } \\
\left.\mathrm{H}_{0}\right)\end{array}$} \\
\hline & & & 6.611 & 8.393 & \\
\hline & & & 4.371 & 5.704 & \\
\hline & & & 3.476 & 4.628 & \\
\hline \multicolumn{6}{|c|}{ Singapore } \\
\hline \multirow[t]{4}{*}{4.642} & \multirow[t]{4}{*}{4} & \multirow{4}{*}{$\begin{array}{l}1 \% \\
5 \% \\
10 \%\end{array}$} & $\mathrm{I}(0)$ & $\mathrm{I}(1)$ & \multirow{4}{*}{$\begin{array}{c}\text { There is cointegration } \\
\text { at } 10 \% \text { sig level (reject } \\
\left.\mathrm{H}_{0}\right)\end{array}$} \\
\hline & & & 6.611 & 8.393 & \\
\hline & & & 4.371 & 5.704 & \\
\hline & & & 3.476 & 4.628 & \\
\hline \multicolumn{6}{|c|}{ Brunei } \\
\hline \multirow[t]{4}{*}{16.893} & \multirow[t]{4}{*}{4} & \multirow{4}{*}{$\begin{array}{l}1 \% \\
5 \% \\
10 \%\end{array}$} & $\mathrm{I}(0)$ & $\mathrm{I}(1)$ & \multirow{4}{*}{$\begin{array}{c}\text { There is cointegration } \\
\text { at } 1 \% \text { sig level (reject } \\
\left.\mathrm{H}_{0}\right)\end{array}$} \\
\hline & & & 6.611 & 8.393 & \\
\hline & & & 4.371 & 5.704 & \\
\hline & & & 3.476 & 4.628 & \\
\hline \multicolumn{6}{|c|}{ The Philippines } \\
\hline \multirow[t]{4}{*}{9.855} & \multirow[t]{4}{*}{2} & \multirow{4}{*}{$\begin{array}{l}1 \% \\
5 \% \\
10 \%\end{array}$} & $\mathrm{I}(0)$ & $\mathrm{I}(1)$ & \multirow{4}{*}{$\begin{array}{l}\text { There is cointegration at } \\
\left.1 \% \text { sig level (reject } \mathrm{H}_{0}\right)\end{array}$} \\
\hline & & & 6.701 & 8.520 & \\
\hline & & & 4.406 & 5.757 & \\
\hline & & & 3.494 & 4.658 & \\
\hline
\end{tabular}

Notes: $1 .{ }^{*}$ Critical values are calculated based on the response surface (Turner 2006)

2. The test is conducted with $\mathrm{k}=3$, unrestricted intercept and no trend

(Source: Authors' computation.) 
Table 5: F-Statistics for Cointegration Relationship (Model 2- Using BB)

\begin{tabular}{|c|c|c|c|c|c|}
\hline $\begin{array}{l}\text { F-test } \\
\text { statistics }\end{array}$ & Lag & $\begin{array}{l}\text { Sig. } \\
\text { level }\end{array}$ & $\begin{array}{l}\text { Adjusted B } \\
\text { Values* (ur } \\
\text { intercept ar }\end{array}$ & $\begin{array}{l}\text { itical } \\
\text { nd) } \\
\text { nd }\end{array}$ & Outcome \\
\hline \multicolumn{6}{|c|}{ Malaysia } \\
\hline \multirow[t]{4}{*}{1.834} & \multirow[t]{4}{*}{2} & \multirow{4}{*}{$\begin{array}{l}1 \% \\
5 \% \\
10 \%\end{array}$} & $\mathrm{I}(0)$ & $\mathrm{I}(1)$ & \multirow[t]{4}{*}{$\begin{array}{l}\text { There is no cointegration } \\
\left.\text { (not reject } \mathrm{H}_{0}\right)\end{array}$} \\
\hline & & & 8.679 & 11.295 & \\
\hline & & & 5.177 & 6.887 & \\
\hline & & & 3.905 & 5.302 & \\
\hline \multicolumn{6}{|c|}{ Indonesia } \\
\hline \multirow{4}{*}{9.897} & \multirow[t]{4}{*}{2} & \multirow{4}{*}{$\begin{array}{l}1 \% \\
5 \% \\
10 \%\end{array}$} & $\mathrm{I}(0)$ & $\mathrm{I}(1)$ & \multirow{4}{*}{$\begin{array}{c}\text { There is cointegration at } \\
5 \% \text { sig level (reject } \mathrm{H}_{0} \text { ) }\end{array}$} \\
\hline & & & 8.319 & 10.791 & \\
\hline & & & 5.037 & 6.683 & \\
\hline & & & 3.831 & 5.187 & \\
\hline \multicolumn{6}{|c|}{ Brunei } \\
\hline \multirow{4}{*}{5.772} & \multirow[t]{4}{*}{1} & & $\mathrm{I}(0)$ & $\mathrm{I}(1)$ & \multirow{4}{*}{$\begin{array}{l}\text { There is cointegration at } \\
\left.10 \% \text { sig level (reject } \mathrm{H}_{0}\right)\end{array}$} \\
\hline & & $1 \%$ & 8.679 & 11.295 & \\
\hline & & $5 \%$ & 5.177 & 6.887 & \\
\hline & & $10 \%$ & 3.905 & 5.302 & \\
\hline
\end{tabular}

Notes: $1 .{ }^{*}$ Critical values are calculated based on response surface (Turner 2006)

2. The test is conducted with $\mathrm{k}=3$, unrestricted intercept and no trend

(Source: Authors' computation.)

For further analysis, the long-run model is developed by normalizing on real GDP per capita for each country and presented in Tables 6 and 7 using each indicator of the digital revolution, respectively.

As for Malaysia, the significant variables which appear to affect growth $(\mathrm{Y})$ in the long-run are capital $(\mathrm{K})$ and digital variable $(\mathrm{MOB})$. The results are expected and confirmed by the findings of several past studies. The finding is consistent with Norhanani (2010) that found a positive and significant effect of physical capital on income or economic growth (lnY) in the long-run. Our results are in line with Kuppusamy and Shanmugam (2007) and Elsadiq (2008, 2010 and 2011) that found digital development such as ICT is positive and significant to the economic growth in the long-run for Malaysia. Investment in digital technology enables the economy to experience an increasing return to scale in the long term. This implies that the diffusion of technology into the economy from 1980 to 2010 become a source of economic efficiency which increases the country's real output. Under the National Transformation (TN50) plan, a new vision was set for the nation to transform the country into a nation among top 
higher ranking countries in the world through the development of digital economy. It is believed that the digital economy would assist Malaysia to boost its national income through sectors which are dominated by the young who are mainly the active contributors to the nation economic activities at present and in the future.

Table 6: Long-Run Estimates (Model 1)

\begin{tabular}{|c|c|c|c|}
\hline \multirow{12}{*}{$\begin{array}{c}\text { Dependent } \\
\text { Variable: } \ln (Y)\end{array}$} & \multicolumn{3}{|c|}{ Independent variables } \\
\hline & $\ln K$ & $\ln L$ & $\operatorname{lnMOB}$ \\
\hline & \multicolumn{3}{|c|}{ Malaysia } \\
\hline & $\begin{array}{c}0.2602^{* * *} \\
(0.022)\end{array}$ & $\begin{array}{l}-0.047 \\
(0.136) \\
\end{array}$ & $\begin{array}{c}0.0524^{* * *} \\
(0.005) \\
\end{array}$ \\
\hline & \multicolumn{3}{|c|}{ Indonesia } \\
\hline & $\begin{array}{l}1.4754 \\
(1.468)\end{array}$ & $\begin{array}{l}-10.667 \\
(16.023)\end{array}$ & $\begin{array}{l}-0.021 \\
(0.057)\end{array}$ \\
\hline & \multicolumn{3}{|c|}{ Singapore } \\
\hline & $\begin{array}{l}0.2419 \\
(0.183)\end{array}$ & $\begin{array}{l}2.0114 \\
(2.000)\end{array}$ & $\begin{array}{l}-0.0433 \\
(0.052)\end{array}$ \\
\hline & \multicolumn{3}{|c|}{ Brunei } \\
\hline & $\begin{array}{c}0.2874 \\
(0.1099)\end{array}$ & $\begin{array}{l}14.621^{*} \\
(4.714)\end{array}$ & $\begin{array}{l}-0.2039 \\
(0.073)\end{array}$ \\
\hline & \multicolumn{3}{|c|}{ The Philippines } \\
\hline & $\begin{array}{c}0.5332^{* * *} \\
(0.089)\end{array}$ & $\begin{array}{l}-1.1597 \\
(0.826)\end{array}$ & $\begin{array}{l}0.029^{*} \\
(0.016)\end{array}$ \\
\hline
\end{tabular}

Notes: standard error in parentheses, ${ }^{* * *}$ significant at $1 \%,{ }^{* *}$ significant at $5 \%$, * significant at $10 \%$

(Source: Authors' computation.)

Table 7: Long-Run Estimates (Model 2)

\begin{tabular}{|c|c|c|c|}
\hline \multirow{6}{*}{$\begin{array}{c}\text { Dependent } \\
\text { Variable: } \ln (Y)\end{array}$} & \multicolumn{3}{|c|}{ Independent variables } \\
\hline & $\ln K$ & $\ln \mathrm{L}$ & $\ln B B$ \\
\hline & \multicolumn{3}{|c|}{ Indonesia } \\
\hline & $\begin{array}{c}0.555^{* * *} \\
(0.030)\end{array}$ & $\begin{array}{c}-0.5212 \\
(0.935)\end{array}$ & $\begin{array}{l}0.0050 \\
(0.006) \\
\end{array}$ \\
\hline & \multicolumn{3}{|c|}{ Brunei } \\
\hline & $\begin{array}{c}-0.0854 \\
(0.069)\end{array}$ & $\begin{array}{c}2.2168 \\
(1.2042)\end{array}$ & $\begin{array}{l}-0.0037 \\
(0.027)\end{array}$ \\
\hline
\end{tabular}

Notes: standard error in parentheses, ${ }^{* * *}$ significant at $1 \%,{ }^{* *}$ significant at $5 \%, *$ significant at $10 \%$

(Source: Authors' computation.) 
Using MOB as digital development indicator, the Philippines is also another country of ASEAN which is found to have a positive and significant relationship between digital development and economic growth in the long-run. A study by Malisuwan, Milindavanij, and Sivaraks (2016) signifies this current finding as it found that the country has risen significantly in the rankings of IDI (ICT Development Index) values over 5 years period from 2010 to 2015. The country's ranking improved from 105 to 98 in global ranking in those years. Using BB in the model, none of the digital variables is significant in the long-run for Indonesia and Brunei. However, capital is significant and positively contributes to the economic growth of Indonesia.

The results for the error correction model (ECM) or short-run model are presented in Tables 8 and 9 for each indicator of the digital variable, respectively. In most cases, digital transformation has given negative implication in short-run to economic growth of ASEAN economies such as for Malaysia and Singapore. There are mixed positive and negative impacts found in the case of Indonesia and Brunei, in which the negative impact is found more often than the positive impact in each case.

Digital development, however, is insignificant to the Philippines in a short period of time. The results are probably due to the digital divide across ASEAN region. The digital divide is an important challenge encountered by these economies in the era of digital revolution due to great differences among the countries both in the stage of development and quality of life. Connectivity of internet, for example, varies from as much as $73 \%$ of the population in Singapore to little more than $1 \%$ in Myanmar which might contribute to the mixed impact of digital development on the economic growth of some countries in short-run. The high cost of internet access mainly causes the digital divide, less demand and less supply or providers to move towards a fully developed digital economy and society particularly to low- and middle-income citizens of ASEAN economies.

Table 8: Error Correction Regressions (Model 1)

\begin{tabular}{|l|l|l|l|l|l|}
\hline \multicolumn{5}{|c|}{ Dependent variable : D(lnY)t } \\
\hline $\begin{array}{l}\text { Independent } \\
\text { variable }\end{array}$ & Malaysia & Singapore & Indonesia & Brunei & $\begin{array}{c}\text { The } \\
\text { Philippines }\end{array}$ \\
\cline { 2 - 6 } & & & $-1.740^{* *}$ & $-21.838^{* * *}$ & $-0.182^{* * *}$ \\
\hline Constant & $1.366^{* * *}$ & $-2.656^{* * *}$ & $(-7.262)$ & $(-13.021)$ & $(-6.294)$ \\
\hline & $(5.777)$ & $(-5.384)$ & $-0.884^{* * *}$ & $-1.009^{* * *}$ & \\
\hline $\mathrm{D}(\operatorname{lnY})_{\mathrm{t}-1}$ & & -0.077 & $(-18.018)$ & $(-10.755)$ & \\
& & $(-0.507)$ & $0.554^{* *}$ & $-1.131^{* * *}$ & \\
\hline $\mathrm{D}(\ln \mathrm{Y})_{\mathrm{t}-2}$ & & $-0.316^{*}$ & $(4.144)$ & $(-20.434)$ & \\
& & $(-2.263)$ & & & \\
\hline
\end{tabular}




\begin{tabular}{|c|c|c|c|c|c|}
\hline $\mathrm{D}(\ln Y)_{\mathrm{t}-3}$ & & & $\begin{array}{l}-0.295 \\
(-2.821)\end{array}$ & $\begin{array}{l}-1.314^{* * *} \\
(-12.135)\end{array}$ & \\
\hline $\mathrm{D}(\ln \mathrm{K})_{\mathrm{t}}$ & $\begin{array}{l}0.286^{* * *} \\
(13.06)\end{array}$ & $\begin{array}{l}-0.234 \\
(-1.861) \\
\end{array}$ & $\begin{array}{l}-0.041 \\
(-1.063)\end{array}$ & $\begin{array}{l}0.127^{* * *} \\
(12.767)\end{array}$ & $\begin{array}{l}0.246^{* * *} \\
(7.680)\end{array}$ \\
\hline $\mathrm{D}(\ln \mathrm{K})_{\mathrm{t}-1}$ & & $\begin{array}{l}-0.483^{* * *} \\
(-3.678)\end{array}$ & $\begin{array}{l}0.234^{* *} \\
(7.514)\end{array}$ & $\begin{array}{l}0.006 \\
(1.671) \\
\end{array}$ & \\
\hline $\mathrm{D}(\ln \mathrm{K}) \mathrm{t}-2$ & & $\begin{array}{l}-0.245^{*} \\
(-2.474)\end{array}$ & $\begin{array}{l}0.149^{* *} \\
(6.938)\end{array}$ & $\begin{array}{l}0.037^{* *} \\
(3.941)\end{array}$ & \\
\hline $\mathrm{D}(\ln \mathrm{K})_{\mathrm{t}-3}$ & & & $\begin{array}{l}0.126^{* *} \\
(4.693)\end{array}$ & $\begin{array}{l}-0.025^{* *} \\
(-6.933)\end{array}$ & \\
\hline $\mathrm{D}(\ln L) \mathrm{t}$ & & $\begin{array}{l}2.695^{* * *} \\
(3.902)\end{array}$ & $\begin{array}{l}-1.641^{* *} \\
(-5.225)\end{array}$ & $\begin{array}{l}-5.130^{* * *} \\
(-15.801)\end{array}$ & \\
\hline $\mathrm{D}(\ln L) \mathrm{t}-1$ & & $\begin{array}{l}3.237^{* * *} \\
(3.797)\end{array}$ & $\begin{array}{l}2.708^{* * *} \\
(8.541)\end{array}$ & $\begin{array}{l}-8.084^{* * *} \\
(-10.224)\end{array}$ & \\
\hline $\mathrm{D}(\ln \mathrm{L}) \mathrm{t}-2$ & & $\begin{array}{l}3.473^{* *} \\
(3.089)\end{array}$ & $\begin{array}{l}-0.618 \\
(-2.624)\end{array}$ & $\begin{array}{l}-3.885^{* * *} \\
(-8.492)\end{array}$ & \\
\hline $\mathrm{D}(\ln L) \mathrm{t}-3$ & & & $\begin{array}{l}-0.303 \\
(-1.190)\end{array}$ & $\begin{array}{l}-5.595^{* * *} \\
(-10.084)\end{array}$ & \\
\hline $\mathrm{D}(\ln \mathrm{MOB})_{\mathrm{t}}$ & $\begin{array}{l}-0.057^{* *} \\
(-2.722)\end{array}$ & $\begin{array}{l}0.0059 \\
(0.097)\end{array}$ & $\begin{array}{l}0.063^{* * *} \\
(8.148)\end{array}$ & $\begin{array}{l}-0.001 \\
(-0.122)\end{array}$ & \\
\hline $\mathrm{D}(\operatorname{lnMOB})_{\mathrm{t}-1}$ & $\begin{array}{l}-0.117^{* * *} \\
(-5.180)\end{array}$ & $\begin{array}{l}-0.324^{* * *} \\
(-5.051)\end{array}$ & $\begin{array}{l}-0.040^{* *} \\
(-6.418)\end{array}$ & $\begin{array}{l}-0.048^{* *} \\
(-7.028)\end{array}$ & \\
\hline $\mathrm{D}(\ln M O B) t-2$ & $\begin{array}{l}-0.057^{* *} \\
(-2.244)\end{array}$ & $\begin{array}{l}-0.272^{* *} \\
(-3.466)\end{array}$ & $\begin{array}{l}-0.103^{* *} \\
(-7.323)\end{array}$ & $\begin{array}{l}0.061^{* *} \\
(7.011)\end{array}$ & \\
\hline $\mathrm{D}(\ln \mathrm{MOB})_{\mathrm{t}-3}$ & & $\begin{array}{l}-0.254^{* *} \\
(-3.306)\end{array}$ & $\begin{array}{l}-0.104^{* * *} \\
(-11.815)\end{array}$ & $\begin{array}{l}-0.075^{* *} \\
(-4.751) \\
\end{array}$ & \\
\hline $\mathrm{ECT}_{\mathrm{t}-1}$ & $\begin{array}{l}-0.679^{* * *} \\
(-5.705)\end{array}$ & $\begin{array}{l}-0.915^{\text {*** }} \\
(-5.450)\end{array}$ & $\begin{array}{l}0.124^{* *} \\
(7.593)\end{array}$ & $\begin{array}{l}-0.398^{* * *} \\
(-12.997)\end{array}$ & $\begin{array}{l}-0.195^{* * *} \\
(-6.781)\end{array}$ \\
\hline $\begin{array}{l}\text { Adjusted R- } \\
\text { square } \\
\text { F-statistic } \\
\text { DW-statistic } \\
\text { Diagnostic } \\
\text { Test: } \\
\text { Jarque-Bera } \\
\text { Fhet } \\
\text { LM }\end{array}$ & $\begin{array}{l}0.914 \\
44.86^{* * *} \\
1.876\end{array}$ & $\begin{array}{l}0.791 \\
7.131^{* * *} \\
3.249\end{array}$ & $\begin{array}{l}0.998 \\
735.8^{* * *} \\
3.653\end{array}$ & $\begin{array}{l}0.984 \\
81.884 \\
2.931\end{array}$ & $\begin{array}{l}0.795 \\
45.665^{\text {*** }} \\
2.067\end{array}$ \\
\hline
\end{tabular}

Notes: 1. t-statistic in parentheses

2. JB normal is the Jarque-Bera Statistic of the Normality Test; Fhet is the F-statistic of the White Heteroskedasticity Test, Lagrange Multiplier (LM) test for Serial correlation

3. *** significant at $1 \%$ level

** significant at $5 \%$ level

* significant at $10 \%$ level

(Source: Authors' computation.) 
The results also show that the digital variable gives a negative and significant impact on the economic growth of Malaysia in short-run. These results are inconsistent with Kuppusamy and Shanmugam (2007) and Elsadiq (2008) who find a positive relationship between ICT and income in the short run. Elsadiq $(2008,2010)$ finds that human capital and ICT contribute positively to the economic growth by introducing total productivity factor (TPF). It is perceived that since Malaysian government had channelled higher investments on digital infrastructure, it might give negative short-run impact on national income but it is believed to be a contributor to economic growth in the long-run period. Tangible evidence of Malaysia's commitment to digital development is the Multimedia Super Corridor (MSC). This $50 \times 15 \mathrm{~km}$ wide corridor stretches from the centre of Kuala Lumpur to Cyberjaya, a newly established city approximately $40 \mathrm{~km}$ south of Kuala Lumpur, and is designed to incubate high technology companies. When the MSC was first announced in 1995, it was estimated that the government would spend RM 28 billion (approximately USD 7.4 billion) to develop the infrastructure and facilities required to attract international high technology companies (Mohamed, Hasan, Dzakiria, \& Kassim, 1999).

Table 9: Error Correction Regressions (Model 2)

\begin{tabular}{|l|l|l|}
\hline \multicolumn{3}{|c|}{ Dependent variable $: \mathrm{D}(\ln Y)_{\mathrm{t}}$} \\
\hline \multirow{2}{|c|}{$\begin{array}{l}\text { Independent } \\
\text { variable }\end{array}$} & \multicolumn{2}{c|}{ Coefficients } \\
\cline { 2 - 3 } Constant & Indonesia & Brunei \\
\hline $\mathrm{D}(\ln \mathrm{Y})_{\mathrm{t}-1}$ & $-1.821^{* * *}$ & $1.697^{* * *}$ \\
& $(-7.137)$ & $(5.889)$ \\
\hline $\mathrm{D}(\operatorname{lnK})_{\mathrm{t}}$ & & -0.0005 \\
& $0.1449^{* * *}$ & $(-0.030)$ \\
\hline $\mathrm{D}(\operatorname{lnK})_{\mathrm{t}-1}$ & $(5.392)$ & \\
\hline $\mathrm{D}(\operatorname{lnL})_{\mathrm{t}}$ & $-0.071^{* * *}$ & $-2.959^{*}$ \\
& $(-4.036)$ & $(-2.107)$ \\
\hline $\mathrm{D}(\operatorname{lnL})_{\mathrm{t}-1}$ & & $-0.051^{* *}$ \\
\hline $\mathrm{D}(\operatorname{lnBB})_{\mathrm{t}}$ & & $(-2.484)$ \\
\hline $\mathrm{D}(\operatorname{lnBB})_{\mathrm{t}-1}$ & & $-0.551^{* * *}$ \\
\hline $\mathrm{ECT} \mathrm{t}-1$ & $-0.425^{* * *}$ & $(-5.885)$ \\
\hline & $(-7.265)$ & \\
\hline
\end{tabular}




\begin{tabular}{|l|l|l|}
\hline Adjusted R- & & \\
square & 0.793 & 0.745 \\
F-statistic & $20.158^{* * *}$ & $10.517^{* * *}$ \\
DW-statistic & 2.397 & 2.545 \\
Diagnostic & & \\
Test: & & \\
Jarque-Bera & 3.948 & 0.812 \\
Fhet & 1.398 & 0.787 \\
LM & 0.647 & 1.408 \\
\hline
\end{tabular}

Notes: 1. t-statistic in parentheses

2. JB normal is the Jarque-Bera Statistic of the Normality Test; Fhet is the F statistic of the White Heteroskedasticity Test, Lagrange Multiplier (LM) test $\mathrm{f}$ for Serial correlation

3. ${ }^{* * *}$ significant at $1 \%$ level

** significant at $5 \%$ level

* significant at $10 \%$ level

(Source: Authors' computation.)

The significance and negative sign of an error correction term (ECT) in almost all cases show the evidence of causality in at least one direction. The coefficients of the lagged error term $\left(\mathrm{ECT}_{\mathrm{t}-1)}\right)$ in both Model 1 and Model 2 are negative and significant at 1 per cent level except for Indonesia (positive sign) in Model 1. The coefficient of -0.679 , for example for Malaysia, indicates a high rate of convergence to equilibrium. Any deviation from the long-run equilibrium between variables is corrected about $68 \%$ for each period to return to the longrun equilibrium level. Singapore experiences the highest rate of convergence in Model 1 with $91.5 \%$. Furthermore, the diagnostic tests in the models indicate no evidence of serial correlation or heteroskedasticity. The models also pass the Jarque-Bera normality test, which indicates that the error terms are normally distributed.

\section{Conclusion and Policy Recommendation}

The study attempts to analyse the relationship between digital development and economic growth in selected ASEAN economies using the small size of sample data. Using bound testing technique of cointegration, the new critical values of the test is recalculated to fit for small sample data based on the response surface suggested by Turner (2006). The long-run impact of digital transformation on economic growth is profound in Malaysia and the Philippines. However, in short-run, most countries in the region, regardless of income level or economic development, encountered negative implication of digital transformation on 
growth probably due to digital divide in those economies which affects the accessibility and connectivity of network in the process of transformation.

Thus, it is recommended that government in each economy of ASEAN continue to promote digital use in all sectors, particularly in services (education and training) which will enhance the efficiency of individuals. The broader usage of ICT and other digital tools, the more informative and efficient the citizens will be. Collaboration among regional government and regulators with International Telecommunication Union (ITU), mobile operators, banks, retailers and other service providers must be initiated to achieve the objective of ASEAN ICT Master Plan 2015. This collaboration will enhance the global interoperability and drive economies of scale to foster the competition and investment in ICT industries of the region. Besides, supportive regulatory policies are required to encourage competition in the ICT markets of the region even though it might involve direct intervention by governments in the market to ensure positive implication of digital transformation on the standard of living is realised in short and long-run periods.

\section{References}

Association of Southeast Asian Nations (ASEAN). (2015). ASEAN Economic Community Blueprint 2025. Jakarta: ASEAN Secretariat.

AT Kearney, \& Axiata. (2015). The ASEAN Digital Revolution. Retrieved from https://www.atkearney.com/documents/10192/7567195/ASEAN+Digital+ Revolution.pdf

Avgerou, C., \& Walsham G. (Ed.). (2000). Information Technology in Context: Studies from the Perspective of Developing Countries. London: Ashgate.

Bailur, S. (2007). Using Stakeholder Theory to Analyze Telecenter Projects. Information Technologies and International Development, 3(3), 61-80

Bhatnagar, S. C., \& Bjorn-Andersen, N. (Ed.). (1990). Information Technology in Developing Countries. Amsterdam: North-Holland.

Bhatnagar, S. C., \& Odedra, M. (Ed.). (1992). Social Implications of Computers in Developing Countries. New Delhi: Tata McGraw-Hill.

Eggleston, K., Jensen R. \& Zeckhauser, R. (2002). Information and Communication Technologies, Markets, and Economic Development. In G. S. Kirkman, P. K. Cornelius, I. D. Sachs, \& K. Schwab (Eds.), The Global Information Technology Report 2001-2002: Readiness for the Networked World (pp. 62-75). New York: Oxford University Press. 
Elsadiq, A. M. (2008). ICT and Human Capital Intensities Effect on Malaysian Productivity Growth. International Research Journal of Finance and Economics, 13, 152- 161.

Elsadiq, A. M. (2010). Human Capital and ICT per Capital Contribution to East Asian Productivity Growth. International Social Science Review, 85(1), 4055.

Elsadiq, A. M. (2011). Assessing the Impact of ICT and Human Capital Impact on Productivity of ASEAN-5 Economies. Journal of Global Management, 1(1), 23-35.

Harris, R. W., Kumar, A. \& Balaji, V. (2003). Sustainable Telecentres? Two Cases from India. In S. Krishna, \& S. Madon (Eds.), The Digital Challenge: Information Technology in the Development Context (pp. 124-135). Aldershot: Ashgate.

Kirkman, G. S., Cornelius, P. K., Sachs, I. D., \& Schwab, K. (Eds.). (2002). The Global Information Technology Report 2001-2002: Readiness for the Networked World. New York: Oxford University Press.

Krishna, S., \& Madon, S. (2002, 29-31 May). Information \& Communication Technologies and Development: New Opportunities, Perspectives \& Challenges. Paper presented at the 7th International Working Conference of IFIP WG 9.4, Indian Institute of Management Bangalore, Bangalore, India.

Kuppusamy, M., \& Shanmugam, B. (2007). Information Communication Technology and Economic Growth in Malaysia. Review of Islamic Economics, 11(2), 87-100.

Malisuwan, S., Milindavanij, D., \& Sivaraks, J. (2016). Analysis of ICT Development in ASEAN Countries. International Journal of Advanced Research in Management (IJARM), 7(2), 1-10.

Mann, C. L. (2004). Information Technologies and International Development: Conceptual Clarity in the Search for Commonality and Diversity. Information Technologies and International Development, 1(2), 67-79.

Mbarika, V. W., Payton, F. C., Kvasny, L., \& Amadi, A. (2007). IT Education and Workforce Participation: A New Era for Women in Kenya? The Information Society, 23(1), 1-18.

Mohamed, A. H., Hasan, H., Dzakiria, H., \& Kassim, A. (1999, October). IT impact on Schools: Overcoming Barriers in Integrating Computers in the Malaysian Primary Schools. Paper presented at the 10th Asian Workshop on IT, Bangi, Malaysia.

Monetary Authority of Singapore. (2018, April). The Promise of Digital Transformation in ASEAN. Macroeconomic Review, 74-81. 
Narayan, P. K. (2004). Reforming Critical Values for the Bounds F-Statistics Approach to Cointegration: An Application to the Tourism Demand for Fiji (Discussion Papers). Melbourne: Department of Economics, Monash University.

Ngwenyama, O., Andoh-Baidoo, F. K., Bollou, F., \& Morawczynski, O. (2006). Is There a Relationship Between ICT, Health, Education and Development? An Empirical Analysis of Five West African Countries from 1997-2003. Electronic Journal on Information Systems in Developing Countries, 23(5), 111.

Norhanani, A. (2010). An Analysis of Human Capital and Economic Growth in The Case of Malaysia: 1970-2008. Unpublished thesis, International Islamic University Malaysia, Gombak, Malaysia.

Odedra-Straub, M., (Ed.). (1996). Global Information Technology and Socio-Economic Development. Nashua, New Hampshire: Ivy League.

Pesaran, M., Shin, Y. \& Smith, R. (2001). Bounds Testing Approaches to the Analysis of Level Relationships. Journal of Applied Econometrics, 16(3), 289326.

Preker, A., Bos, E., Wang, J., Peabody, I., \& Jamison, D. T. (1999). Measuring Country Performance on Health. Washington DC: World Bank.

Sahay, S. (2000, 24-26 May). Information Flows, Local Improvisations and Work Practices. Paper presented at the $6^{\text {th }}$ International Working Conference of IFIP WG 9.4, Cape Town, South Africa.

Turner, P. (2006). Response Surfaces for an F-Test for Cointegration. Applied Economics Letters, 13, 479-482.

Wade, R. (2004). Bridging the Digital Divide: New Route to Development or New Form of Dependency? In C. Avgerou, C. Ciborra, \& F. Land (Eds.), The Social Study of Information and Communication Technology: Innovation, Actions, and Contexts (pp. 185-206). Oxford: Oxford University Press.

Warschauer, M. (2003). Dissecting the "Digital Divide": A Case Study in Egypt. The Information Society, 19(4), 297-304.

Date Received: 9 October 2019 Date of Acceptance: 15 December 2019 